\title{
Erratum to: Histamine release from rat mast cells induced by the metabolic activation of drugs of abuse into free radicals
}

\author{
M. G. Di Bello • E. Masini - C. Ioannides • J. F. Ndisang •
}

S. Raspanti · T. Bani Sacchi $\cdot$ P. F. Mannaioni

Published online: 11 December 2012

(C) Springer Basel 2012

Erratum to: Inflamm Res (1998) 47:122-130

DOI 10.1007/s000110050299

In the original publication of the article, one of the author's given and family name has been inadvertently swapped. The correct author name should read as J. F. Ndisang. The complete author group is given below:

M. G. Di Bello, E. Masini, C. Ioannides, J. F. Ndisang, S. Raspanti, T. Bani Sacchi and P. F. Mannaioni

The online version of the original article can be found under doi:10.1007/s000110050299.

M. G. Di Bello - E. Masini · J. F. Ndisang - S. Raspanti ·

P. F. Mannaioni $(\bowtie)$

Department of Preclinical and Clinical Pharmacology,

V.le G.B. Morgagni 65, I-50134 Florence, Italy

e-mail: mannaion@stat.ds.unifi.it

C. Ioannides

School of Biological Sciences, University of Surrey,

Guildford, GU2 5XH Surrey, UK

T. Bani Sacchi

Department of Human Anatomy and Histology,

University of Florence, V.le G.B. Morgagni 65,

I-50134 Florence, Italy 